\title{
Effect of Gestational Age and Birth Weight on Serum Creatinine in the First Week of Newborn Life
}

\author{
${ }^{1}$ Vijaya L Ayyala, ${ }^{2}$ Narendra Devabathina, ${ }^{3}$ Prakash Gurappagari
}

\begin{abstract}
Introduction: Serum creatinine concentration in health is essentially a function of muscle mass. We designed a prospective study to know the influence of gestational age and birth weight on creatinine in the first week of life.
\end{abstract}

Materials and methods: A total of 218 neonates were enrolled during a 2-year study period (May 2014-April 2016) at Kamineni Hospitals, Hyderabad, India. The study group was categorized based on gestational age [very preterm (VPT), preterm (PT), and term] and birth weight [very low birth weight (VLBW), low birth weight (LBW), and normal birth weight (NBW)]. The serum creatinine was assayed on the day of delivery in the mother and on days $0,3,5$, and 7 in the neonates. The method of estimation of serum creatinine was by the modified kinetic Jaffe's reaction.

Results: Serum creatinine was high in the VPT neonates (28-33 weeks of gestational age) and VLBW neonates $(<1.5 \mathrm{~kg})$ on day 0 . An increase in mean serum creatinine was recorded on day 3 in VPT and VLBW neonates. Mean neonatal serum creatinine in all the subgroups based either on gestational age or birth weight decreased on day 7 .

Conclusion: The serum creatinine in the first week of a newborn should be interpreted cautiously as the kidneys are in the process of maturation. High serum creatinine in neonates with insignificant muscle mass is a reflection of maternal serum creatinine coupled with an immature kidney.

Keywords: Low birth weight, Preterm, Serum creatinine, Term, Very preterm.

How to cite this article: Ayyala VL, Devabathina N, Gurappagari P. Effect of Gestational Age and Birth Weight on Serum Creatinine in the First Week of Newborn Life. Indian J Med Biochem 2017;21(2):131-135.

Source of support: Nil

Conflict of interest: None

\section{INTRODUCTION}

Serum creatinine assay is a widely accepted index of renal function. It is an important and reliable indicator

\footnotetext{
${ }^{1}$ Associate Professor, ${ }^{2}$ Senior Resident, ${ }^{3}$ Tutor

${ }^{1,3}$ Department of Biochemistry, Kamineni Academy of Medical Sciences and Research Centre, Hyderabad, Telangana, India

${ }^{2}$ Department of Pediatrics, Kamineni Hospitals, Hyderabad Telangana, India

Corresponding Author: Vijaya L Ayyala, Associate Professor Department of Biochemistry, Kamineni Academy of Medical Sciences and Research Centre, Hyderabad, Telangana, India Phone: +914024022222, e-mail: vijayamalla09@gmail.com
}

of renal health because its biological reference intervals in the serum are relatively constant during the lifetime of an adult individual without a superimposed renal failure.

The amino acids glycine, arginine, and methionine participate in creatine biosynthesis. Glycine and arginine together form guanidoacetate. Guanidoacetate is methylated by S-adenosyl methionine (activated methionine) to creatine. Creatine, by a nonenzymatic, irreversible, and spontaneous reaction, is converted to creatinine, which is an anhydride of creatine. Approximately, 1 to $2 \%$ of muscle creatine is converted to creatinine each day. ${ }^{1-3}$ Creatinine levels are relatively constant.

In addition, creatinine is an ideal marker of glomerular filtration rate (GFR). The advantage of creatinine is that it is endogenously produced in the muscle at a constant rate and filtered freely by the glomerulus. Unlike urea, it is not reabsorbed by the renal tubule. On the contrary, it is secreted into the renal tubule. Creatinine clearance, hence, overestimates GFR. The affordability of creatinine assay is another reason; it is a widely accepted index of renal function. The GFR is low in fetal and neonatal life. It increases after birth and reaches approximately $20 \mathrm{~mL} / \mathrm{min} / 1.73 \mathrm{~m}^{2}$ at 1 month of age in term and PT neonates. ${ }^{4,5}$

The aim of the present study is to assess the influence of gestational age and birth weight on serum creatinine levels in the first week of a newborn infant. We chose this study in the light of the fact that creatinine concentration is a function of muscle mass and a neonate in the first week of life with very little or insignificant muscle mass showing a high serum creatinine is intriguing.

\section{MATERIALS AND METHODS}

The study design is a prospective study.

The study was conducted in the Department of Biochemistry, Kamineni Hospitals, Hyderabad, India, in collaboration with the Department of Pediatrics.

Hemodynamically stable neonates admitted in the neonatal intensive care unit with transient hyperbilirubinemia and mild respiratory distress were recruited into the study during May 2014 to April 2016.

Study was approved by the Institutional Ethical Committee and informed consent was obtained from the mothers of the neonates who were included in our study. 
A total of 218 neonates were enrolled, who were divided into three subgroups based on the gestational age and birth weight. Subgroups based on the criteria of gestational age are given the suffix "a" and subgroups formed on the criteria of birth weight are given the suffix "b."

- Group Ia - VPT (28-32 weeks)

- Group IIa - PT (33-37 weeks)

- Group IIIa - Term (38-42 weeks)

- Group Ib - VLBW $(<1.5 \mathrm{~kg})$

- Group IIb - LBW (1.5-2.5 kg)

- Group IIIb - NBW (>2.5 kg) $)^{6}$

About $2 \mathrm{~mL}$ of venous blood was collected from the mother at the time of delivery, and serum was assayed for creatinine by the modified kinetic Jaffe's method. About $2 \mathrm{~mL}$ of venous blood was drawn on days $0,3,5$, and 7 from every neonate in the pediatric serum vaccutainers and centrifuged at 3,000 rpm for 10 minutes. The serum thus collected was assayed for creatinine by the modified kinetic Jaffe's method on the fully automated analyzer, mindray BS 380.

Statistical analysis was performed using the Statistical Package for the Social Sciences 17 version. Significance test was done by analysis of variance (ANOVA).

\section{DISCUSSION}

The results in Tables 1 and 2 clearly indicate that VLBW neonates include VPT and some PT neonates, and LBW group includes predominantly PT neonates and some term neonates. Out of a total of 64 term neonates, only 36 have NBW, which is a meager $56 \%$. Low birth weight in term neonates can be attributed to preeclampsia in the mothers. In our study, the incidence of preeclampsia in mothers of VPT neonates is $56.6 \%, 49.5 \%$ in mothers of PT neonates, and $15.6 \%$ in term babies. Preeclampsia during pregnancy is associated with LBW.,

The mean maternal creatinine in the three groups based on gestational age showed a decreasing trend, i.e., mothers of VPT infants have a higher mean serum creatinine, followed by the PT and term neonates' mean

Table 1: Demographic data of the subgroups la, Ila, and IIla

\begin{tabular}{llll}
\hline $\begin{array}{l}\text { Gestational } \\
\text { age }\end{array}$ & $\begin{array}{l}\text { 28-32 weeks } \\
\text { (VPT neonates) }\end{array}$ & $\begin{array}{l}\text { 33-37 weeks } \\
\text { (PT neonates) }\end{array}$ & $\begin{array}{l}\text { 38-42 weeks } \\
\text { (term neonates) }\end{array}$ \\
\hline $\begin{array}{l}\text { No. of } \\
\text { neonates }\end{array}$ & 53 & 101 & 64 \\
$\begin{array}{l}\text { Male:female } \\
\text { ratio }\end{array}$ & $1.2: 1$ & $1.3: 1$ & $1.6: 1$ \\
\hline
\end{tabular}

Table 2: Demographic data of the groups Ib, Ilb, IIlb

\begin{tabular}{llll}
\hline Birth weight & VLBW & LBW & NBW \\
\hline Number of neonates & 74 & 108 & 36 \\
Male:female ratio & $1.6: 1$ & $1.3: 1$ & $1.1: 1$ \\
\hline
\end{tabular}

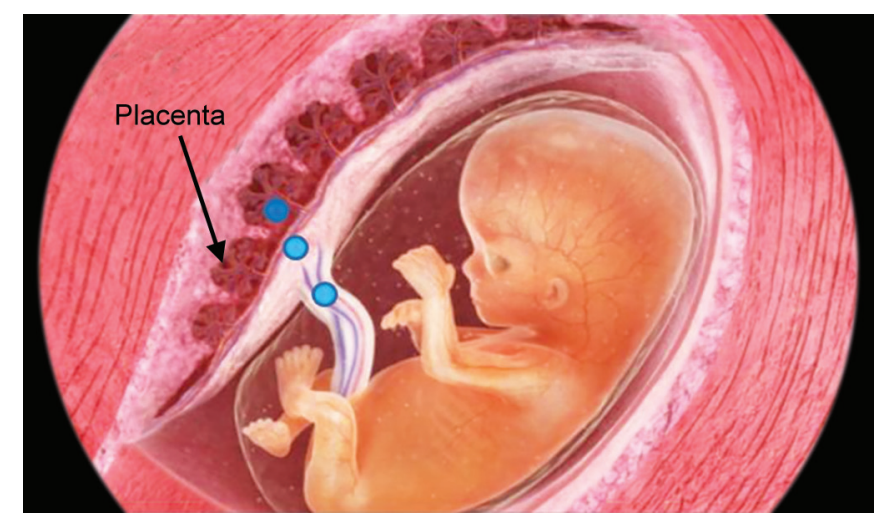

Fig. 1: Bidirectional movement of creatinine through placenta

maternal creatinine (Graph 1). A higher incidence of preeclampsia in the mothers of VPT neonates and PT neonates is responsible for a raised creatinine in them. ${ }^{9-11}$ The neonates of the VPT, PT, and term groups also showed a similar trend, indicating a reflection of the maternal serum creatinine in the neonates. ${ }^{12}$ According to studies by Guignard and Drukker, ${ }^{13}$ creatinine being a small molecular weight peptide passes bidirectionally through the placenta, i.e., creatinine passes from the mother to the fetus and fetus to the mother as well. Maternal creatinine equilibrates with the fetal creatinine (Fig. 1). This hypothesis explains the high creatinine in all the neonates at the time of birth, despite the insignificant muscle mass.

The mean neonatal creatinine on day 0 in the VPT and PT groups was found to be higher than that of their mean maternal creatinine concentrations (Graph 1). The term neonates have a lower mean creatinine compared with the mean maternal serum creatinine (Table 3). From our findings and works of previous workers, we understand that creatinine levels in neonates reflect maternal muscle mass. But a conspicuously higher neonatal creatinine in the VPT group in comparison with the maternal creatinine intrigued

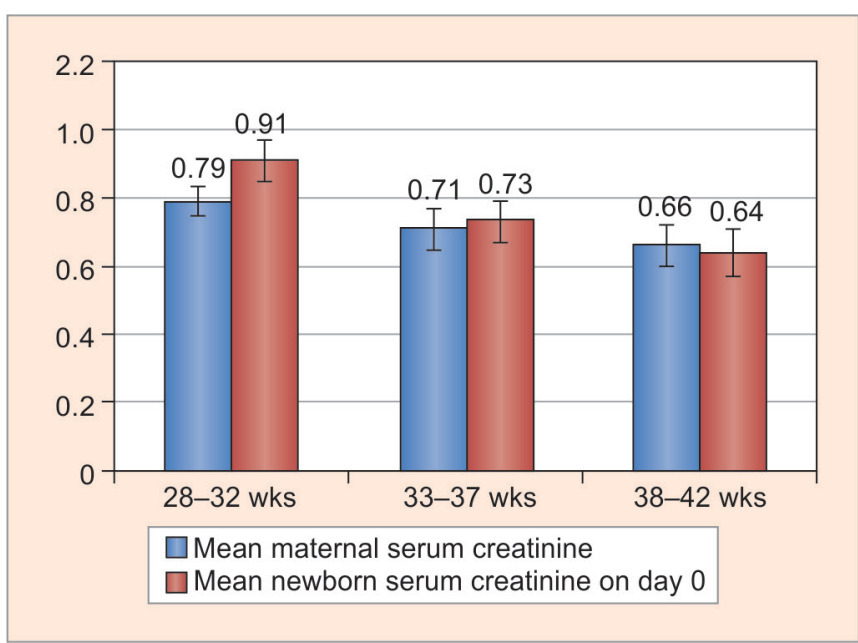

Graph 1: Mean maternal creatinine and the mean neonatal creatinine in VPT, PT, and term neonates on day 0 
Table 3: Mean maternal serum creatinine on day 0 and mean neonatal serum creatinine on days $0,3,5$, and 7 in the subgroups based on gestational age (la, Ila, and IIla)

\begin{tabular}{llll}
\hline & $\begin{array}{l}\text { Group la } \\
\text { (VPT } \\
\text { neonates) } \\
\mathrm{mg} / \mathrm{dL}\end{array}$ & $\begin{array}{l}\text { Group Ila } \\
(P T \text { neonates }) \\
\mathrm{mg} / \mathrm{dL}\end{array}$ & $\begin{array}{l}\text { Group IIla } \\
\text { (Term } \\
\text { neonates) } \\
\mathrm{mg} / \mathrm{dL}\end{array}$ \\
\hline $\begin{array}{l}\text { age } \\
\text { Maternal serum }\end{array}$ & $0.79 \pm 0.06$ & $0.71 \pm 0.07$ & $0.66 \pm 0.07$ \\
$\begin{array}{l}\text { creatinine } \\
\text { Neonatal serum } \\
\text { creatinine on day } 0\end{array}$ & $0.91 \pm 0.06$ & $0.73 \pm 0.06$ & $0.64 \pm 0.06$ \\
$\begin{array}{l}\text { Neonatal serum } \\
\text { creatinine on day } 3\end{array}$ & $1.08 \pm 0.09$ & $0.6 \pm 0.07$ & $0.51 \pm 0.07$ \\
$\begin{array}{l}\text { Neonatal serum } \\
\text { creatinine on day } 5 \\
\text { Neonatal serum } \\
\text { creatinine on day } 7\end{array}$ & $0.8 \pm 0.06$ & $0.49 \pm 0.08$ & $0.42 \pm 0.05$ \\
\hline
\end{tabular}

us. On introspection, we rationalized that the basic denominator in the VPT and PT groups is prematurity. It is just that the degree of prematurity is more in the VPT group, which is reflected as a higher creatinine. A higher creatinine indicates an ineffective renal clearance. Term neonates on day 0 , on the contrary, have lower creatinine levels in comparison with the VPT and pre groups and even when compared with their maternal counterparts. This finding clearly attributes the role of mature kidney function in the term neonates. Guignard and Drukker ${ }^{13}$ attributed a higher plasma creatinine in the VPT and PT groups to a backflow of creatinine due to creatinine reabsorption across the tubules (Fig. 2). As the fetus reaches term at around 38 weeks, the tubules become impermeable and prevent the backflow of creatinine, thus facilitating creatinine clearance. In short, the high creatinine in the premature groups is not just a reflection of the maternal creatinine, but also compounded by an immature functioning kidney.

On day 3, the mean creatinine in the VPT group peaked higher when compared with day 0 (Graph 2). The PT and

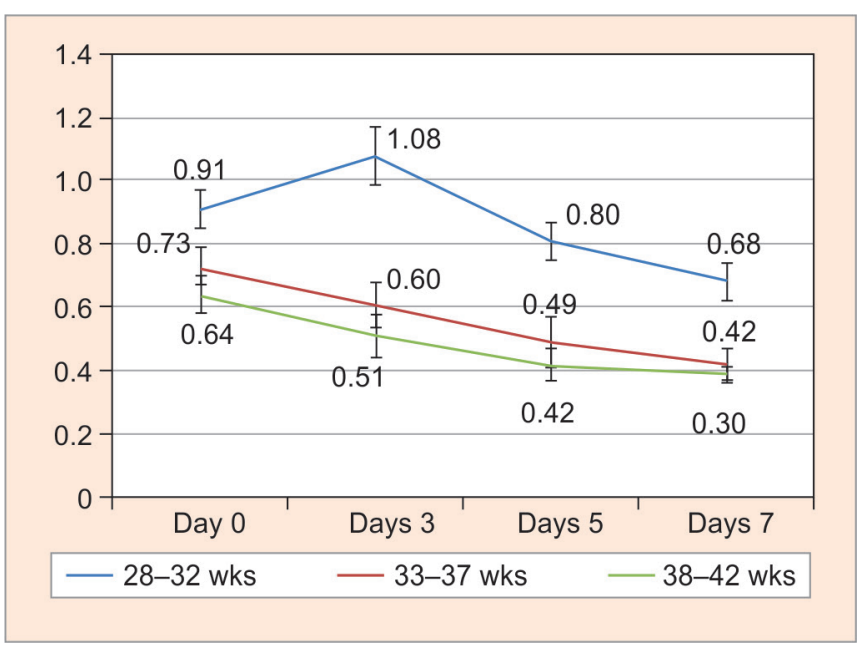

Graph 2: Decreasing levels of mean serum creatinine in VPT, $\mathrm{PT}$, and term groups

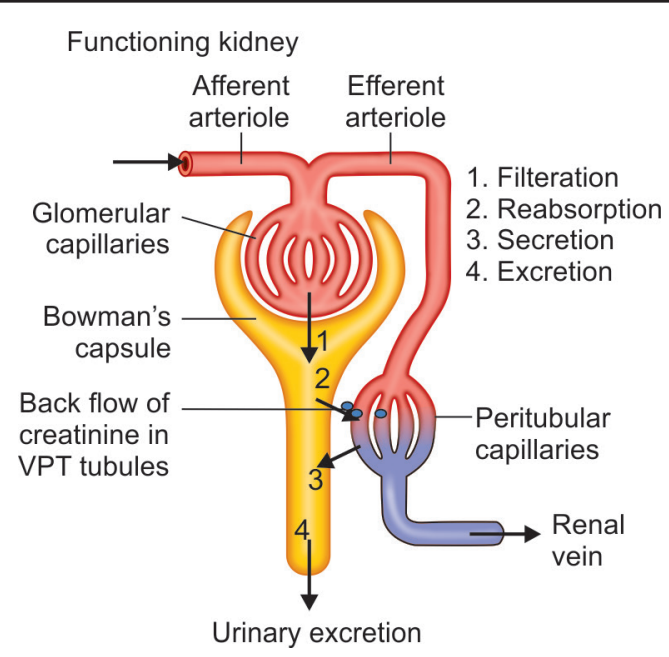

Fig. 2: Reabsorption of creatinine into peritubular capillaries

term groups showed a decreasing trend in creatinine from the time of birth which is statistically significant (Table 4). A higher creatinine on day 3 in the VPT plagued us, considering the fact that the fetomaternal circulation was dissociated 48 hours back and no more maternal creatinine can enter the neonatal circulation. Iacobelli et $\mathrm{al}^{14}$ also observed that serum creatinine increases in the first 48 hours in VPT neonates. Creatinine peaks significantly around the second day of life. ${ }^{15,16}$ This according to Miall et $\mathrm{al}^{17}$ is due to a poor creatinine clearance in the VPT neonates. According to Lao et al ${ }_{1}^{18}$ Larsson et $a l,{ }^{19}$ and Pitkin and Reynolds, ${ }^{20}$ fetal creatinine equilibrates with maternal creatinine in utero. After birth, neonatal serum creatinine concentration is a reflection of the infant's own rates of creatinine metabolism and excretion. The exogenous creatinine load acquired in utero from the mother, reequilibration of serum creatinine after fetomaternal dissociation, and premature kidneys incapable of effective creatinine clearance are all contributing factors for peaking of serum creatinine on the third day of extrauterine life in the VPT group. Lawrence et al demonstrated that the most premature neonates show a higher peak in plasma creatinine around day 2 and a sluggish fall in creatinine levels thereafter.

An encouraging finding was that the creatinine on day 5 in the VPT showed a significant decrease and was almost comparable with the maternal creatinine (Table 3). In the PT and term groups, the creatinine continued to decrease further. Creatinine clearance was increasing in all neonates, albeit slowly in the VPT neonates. This finding clearly indicates the process of a slow maturation in the VPT group.

Mean serum creatinine on day 7 in the VPT, PT, and term groups was significantly low when compared with day 0 . All the neonates were discharged subsequently and none of them developed renal failure (Table 3).

The mean creatinine on day 0 in VLBW neonates was found to be higher than the maternal creatinine (Graph 3). A similar finding was reported by Auron and Mhanna ${ }^{21}$ 


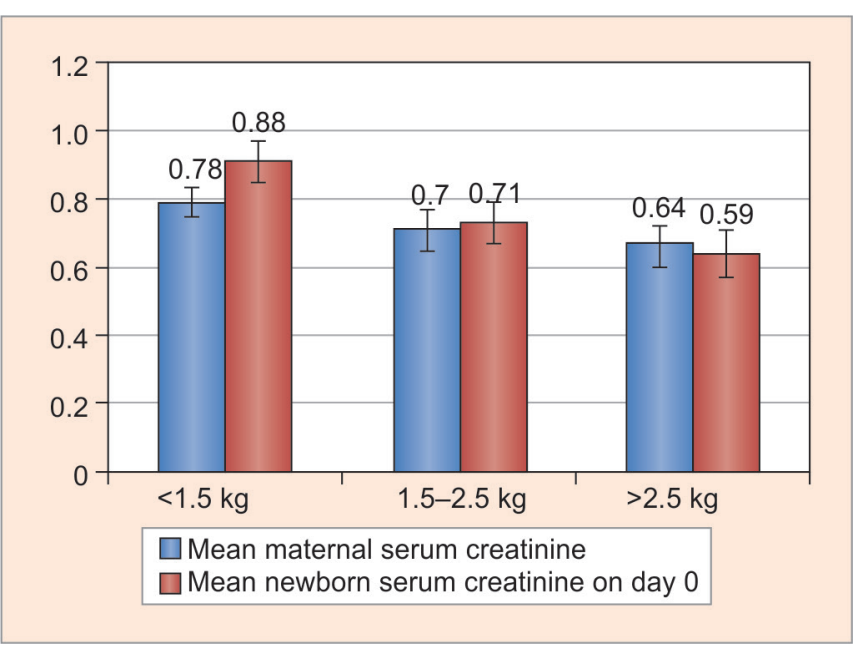

Graph 3: Mean maternal creatinine vs mean neonatal creatinine in VLBW, LBW, and NBW groups on day 0

who observed high creatinine in neonates with little muscle mass. The serum creatinine on day 0 in the LBW group was almost the same as the maternal creatinine, which reiterates our previous finding that neonatal creatinine is a reflection of maternal creatinine. The NBW neonate's creatinine was below the maternal creatinine levels, indicating the greater excretion of creatinine due to functionally mature kidneys.

Mean creatinine peaked on day 3 in VLBW neonates (Graph 4). Creatinine decreased in LBW and NBW neonates (Table 5). This finding clearly shows a delay in the maturation of the kidney in VLBW babies. Renal tubular reabsorption of creatinine and decreased creatinine clearance in the VLBW neonates contribute to the creatinine peak around day 3.

Another encouraging finding is that mean creatinine decreased on day 5 in all the groups, such as the VLBW, LBW, and NBW which is statistically significant (Table 6). A clear downward trend could be appreciated in all the groups. This clearly demonstrates the maturation of the kidney even in VLBW babies (Graph 4).

The creatinine showed a continuing downward trend in VLBW, LBW, and NBW neonates on day 7, further emphasizing the transition from premature to mature kidneys.

We observed similar findings in VPT vs VLBW, PT vs LBW, and term vs NBW neonates. The inevitable question is "Is gestational age a better indicator of maturity or birth weight?" Mean creatinine in VPT neonates is $0.91 \mathrm{mg} / \mathrm{dL}$ and mean creatinine in VLBW neonates on the same day 0 is $0.88 \mathrm{mg} / \mathrm{dL}$. The difference can be attributed to inclusion of a few PT babies in the VLBW group. The PT neonates have a lower mean creatinine when compared with the VPT group. But, statistical analysis by regression did not show any significance.

We would like to conclude that the sharp rise in creatinine should not be the lone criteria in diagnosing renal

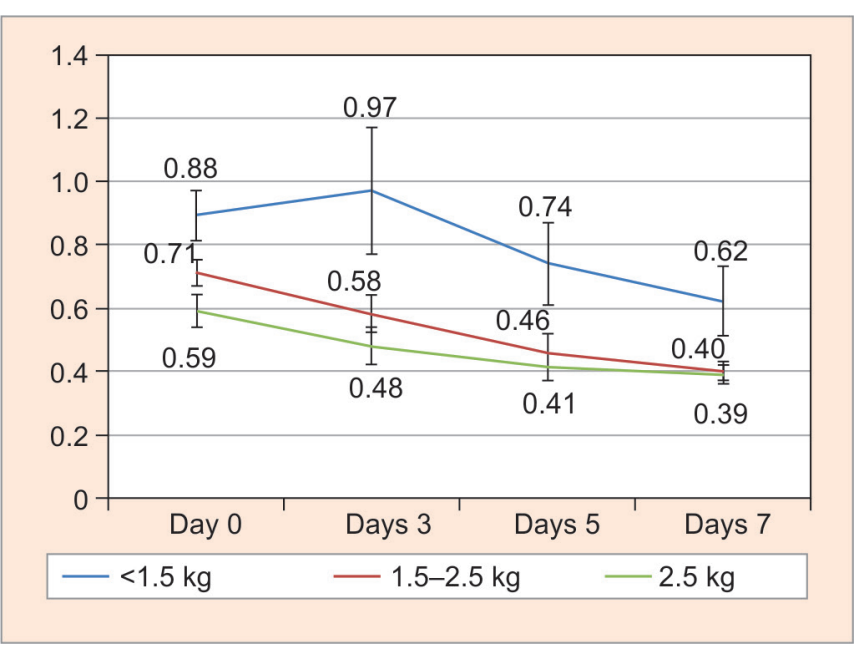

Graph 4: Decreasing trend in mean creatinine levels of VLBW, LBW, and NBW neonates on days $0,3,5$, and 7

Table 4: Significance test ANOVA within the groups

\begin{tabular}{lccc}
\hline Significance test & la vs Ila & la vs IIla & Ila vs IIla \\
\hline $\mathrm{p}$-value & $<0.001$ & $<0.001$ & $<0.001$ \\
\hline
\end{tabular}

Table 5: Significance test ANOVA within the groups

\begin{tabular}{lccc}
\hline Significance test & Ib vs Ilb & Ib vs IIIb & IIb vs IIIb \\
\hline p-value & $<0.001$ & $<0.001$ & $<0.001$ \\
\hline
\end{tabular}

Table 6: Mean maternal serum creatinine and mean neonatal serum creatinine on days $0,3,5$, and 7 in VLBW, LBW, and NBW

\begin{tabular}{llll}
\hline Birth weight & $\begin{array}{l}\text { Group Ib } \\
(\text { VLBW) } \mathrm{mg} / \mathrm{dL} L\end{array}$ & $\begin{array}{l}\text { Group IIb } \\
(\mathrm{LBW}) \mathrm{mg} / \mathrm{dL}\end{array}$ & $\begin{array}{l}\text { Group IIIb } \\
(\mathrm{NBW}) \mathrm{mg} / \mathrm{dL}\end{array}$ \\
\hline $\begin{array}{l}\text { Maternal } \\
\text { creatinine }\end{array}$ & $0.78 \pm 0.05$ & $0.70 \pm 0.06$ & $0.64 \pm 0.06$ \\
$\begin{array}{l}\text { Neonatal serum } \\
\text { creatinine on } \\
\text { day } 0\end{array}$ & $0.88 \pm 0.08$ & $0.71 \pm 0.04$ & $0.64 \pm 0.06$ \\
$\begin{array}{l}\text { Neonatal serum } \\
\text { creatinine on } \\
\text { day } 3\end{array}$ & $0.97 \pm 0.2$ & $0.58 \pm 0.06$ & $0.48 \pm 0.06$ \\
$\begin{array}{l}\text { Neonatal serum } \\
\text { creatinine on } \\
\text { day } 5\end{array}$ & $0.74 \pm 0.13$ & $0.46 \pm 0.06$ & $0.41 \pm 0.04$ \\
$\begin{array}{l}\text { Neonatal serum } \\
\text { creatinine on } \\
\text { day } 7\end{array}$ & $0.62 \pm 0.11$ & $0.40 \pm 0.03$ & $0.39 \pm 0.03$ \\
\hline
\end{tabular}

failure in the sick VPT and VLBW neonates, who are in the rapid phase of physiological adaptation to extrauterine life. Larger cohorts are required to conclusively know whether gestational age is a better indicator of prematurity or birth weight is a better indicator.

\section{REFERENCES}

1. Borsook H, Dubnoff JW. The hydrolysis of phosphocreatine and the origin of urinary creatinine. J Biol Chem 1947 May;168(2):493-510. 
2. Goldman R. Creatinine excretion in renal failure. Proc Soc Exp Biol Med 1954 Mar;85(3):446-450.

3. Heymsfield SB, Arteaga C, McManus C, Smith J, Moffitt S. Measurement of muscle mass in humans: validity of the 24-hour urinary creatinine method. Am J Clin Nutr 1983 Mar;37(3):478-494.

4. Wahl EF, Lahdes-Vasama TT, Churchill BM. Estimation of glomerular filtration rate and bladder capacity: the effect of maturation, ageing, gender and size. Br J Urol Int 2003 Feb;91(3):255-262.

5. Junge W, Wilke B, Halabi A, Klein G. Determination of reference intervals for serum creatinine, creatinine excretion and creatinine clearance with an enzymatic and a modified Jaffe method. Clin Chim Acta 2004 Jun;344(1-2):137-148.

6. Battaglia FC, Lubchenco LO. A practical classification of new born infants by weight and gestational age. J Pediatr 1967 Aug;71(2):159-163.

7. Long PA, Abell DA, Beischer NA. Fetal growth retardation and pre eclampsia. Br J Obstet Gynaecol 1980 Jan;87(1): 13-18.

8. Sibai BM, Spinnato JA, Watson DL, Hill GA, Anderson GD. Pregnancy outcome in 303 cases with severe preeclampsia. Obstet Gynaecol 1984 Sep;64(3):319-325.

9. Egwuatu VE. Plasma concentration of urate, urea and creatinine in Nigerian primigravidae with pre-eclampsia. Trop Geogr Med 1986 Mar;38(1):11-15.

10. Hassan TJ, Sadaruddin A, Jafarey SN. Serum calcium, urea and uric acid levels in pre-eclampsia. J Pak Med Assoc 1991 Aug;41(8):183-185.

11. Mustaphi R, Gopalan S, Dhaliwal L, Sarkar AK. Hyperuricemia and pregnancy induced hypertension-reappraisal. Ind J Med Sci 1996 Mar;50(3):68-71.
12. Manzke H, Spreter von Kreudenstein P, Dörner K, Kruse K. Quantitative measurements of the urinary excretion of creatinine, uric acid, hypoxanthine, xanthine, Uracil, cyclic AMP and cyclic GMP in healthy new born infants. Eur J Pediatr 1980 Mar;133(2):157-161.

13. Guignard JP, Drukker A. Why do newborn infants have a high plasma creatinine? Pediatrics 1999 Apr;103(4):e49.

14. Iacobelli S, Bonsante F, Ferdinus C, Labenne M, Gouyon JB. Factors affecting post natal changes in serum creatinine in preterm infants with gestational age $<32$ weeks. J Perinatol 2009 Mar;29(3):232-236.

15. Rudd PT, Hughes EA, Placzek MM, Hodes DT. Reference ranges for plasma creatinine during the first month of life. Arch Dis Child 1983 Mar;58(3):212-215.

16. Bueva A, Guignard JP. Renal function in pre term neonates. Pediatr Res 1994 Nov;36(5):572-577.

17. Miall LS, Henderson MJ, Turner AJ, Brownlee KG, Brocklebank JT, Newell SJ, Allgar VL. Plasma creatinine rises dramatically in the first 48 hours of life in pre term infants. Pediatrics 1999 Dec;104(4);e76.

18. Lao TT, Loong EP, Chin RK, Lam YM. Renal function in the new born. New born creatinine related to birth weight, maturity and maternal creatinine. Gynecol Obstet Invest 1989;28(2):70-72.

19. Larsson A, Palm M, Hansson LO, Axelsson O. Reference values for clinical chemistry tests during normal pregnancy. BJOG 2008 Jun;115(7):874-881.

20. Pitkin RM, Reynolds WA. Creatinine exchange between mother, fetus, and amniotic fluid. Am J Physiol 1975 Jan;228(1):231-237.

21. Auron A, Mhanna MJ. Serum creatinine in very low birth weight infants during their first days of life. J Perinatol 2006 Dec;26(12):755-760. 